\title{
The Myth of Creation from Malaysia and Australia: A Comparative Study
}

\author{
Halimah Mohamed Ali \\ Universiti Sains Malaysia \\ halimah@usm.my
}

Abstract: Myths are sacred narratives. They describe how this world was created and also how the living beings came into existence as they exist today. Myths are normally said to be untrue thus unbelievable. However, there are thinkers that say that myths are at times a higher form of truth. These types of myths can be labelled as sacred myths. The study of myths is interdisciplinary and international. This essay will analyse the myths of creation from two countries, Malaysia and Australia. The myths chosen are aboriginal myths. The theoretical framework will be built using the theory of myths by G.S. Kirk (1984) and Theodor H. Gaster and simple definitions on myths. These will be used to analyse the selected texts, from Malaysia titled "Asal Usul Ka'adat", dan "Asal Usul Padi", and from Australia titled "The First Men and Women" dan "The Discovery of Fire".

\section{INTRODUCTION}

Myths are sacred narratives. They describe how this world was created and also how the living beings came into existence as they exist today. Myths are normally said to be untrue thus unbelievable. However, there are thinkers that say that myths are at times a higher form of truth. These types of myths can be labeled as sacred myths. The study of myths is interdisciplinary and international.

This essay will analyse the myths of creation from two countries, Malaysia and Australia. The myths chosen are aboriginal myths. The theoretical framework will be built using the theory of myths by G.S. Kirk (1984) and Theodor H. Gaster and simple definitions on myths. These will be used to analyse the selected texts, from Malaysia titled "Asal Usul Ka'adat", dan "Asal Usul Padi", and from Australia titled "The First Men and Women" dan "The Discovery of Fire".

\section{THEORY}

\section{Defining Myth}

Myth is a social phenomenon. Myths are ethnocentric. It has been described as a scandalous science by the Western scholars who are biased against its ethnocentricism. Synm'JVe des Bouvrie in her essay The definition of myth.Titled Symbolical phenomena in ancient culture (p. 13) discusses Marcel Detienne's thoughts and arguments of myth. According to her,

He has rightly pointed to the inacceptability of Western habits of relegating stories presented by 'the natives' to 'myth' while accepting our own religious and other tales as 'the truth,' thus separating the grotesque from the sensible, the immoral from the moral. 'L'anthropologue est un homme des frontieres: entre les sauvages et les civilises, entre l'enfance de l'humanite et son age adulte, entre nous et nos and tres: 3 This attitude is of course nothing but an instance of the universal (?) habit of confronting the 'other' vs. the 'self,' combined with a Western 'colonial mentalite' of assuming a fundamental segregation between the culture of 'the natives' 
and our Western, contemporary, 'enlightened' world. The use of the term 'myth' in this sense, a category for defining other people as less developed is of course inherent in Wilhelm von Nestle's 'Vom Mythos zum Logos' concept.

According to her this kind of bias is also present in the work of G. S. Kirk that will be used in the analysis of the text. Bouverie in her further arguments on myths takes up the views of Claude Calame and Detienne. Myth is looked at as a problem by all three scholars. Accroding to Boverie who uses a Eurocentric perspective (p.12),

... myth is not an entity with any ontological existence, but rather a

Western category which originated in the early days of anthropological thought,

during the Enlightenment. As a spatially and temporally marked tool of

classification, the category "myth" is generated by the act of looking.

Myth is said to have come into being from the gaze of a human. Boverie traces the origins of myth to the Enlightenment and looks at anthropological thought in order to define myth.

Bouvrie goes as far as the ancient Greek era to define myth. According to her (p.13),

Furthermore Calame points to the fact that the Greeks lacked a term for what

we identify as 'myth.' However, this fact that the Greek term 'muthos' (J..Lu8o )

does not refer to a distinct category of tales among the (early) Greeks, does not

need to halt us either. There were some expressions which referred to what many

would call 'myth; the great exploits of ancestors, heroes and demi-gods, understood

as belonging to the more or less remote past. The terminology which the

Greeks could apply to this past wasta palaia ('ta naA.aui), 'the ancient [things,

events] . 'What is interesting about this term is that it does not refer to a particular

kind of tales, but to certain events, which underscores their status as reality. About

these events, according to a wide-spread opinion, it was difficult to achieve firm

knowledge, and poets are often accused of making up a story because of this lack

of precise knowledge. This does not imply that the basic truth of the existence of

gods and heroes is being denied. The absence of a term for 'myth' may be due to

the elusive nature of the phenomena in question. It may in fact be an encouraging

sign of the serious status of the tale.

However, the Greeks did not have a term for myth. The nearest term that can be detected is 'muthos', and this term does not in any way come close to describing a myth or defining it. Wasta palaia is another term that is used to describe the ancients and their culture. Nevertheless, this does not refer to tales, it refers to events and emphasizes that the events which include exploits of ancestors, heroes and demi-gods are a reality. Thus it can be deduced that the Greeks believe in legends, thus the reason for the lack of the term or definition of myth in anceint Greek tradition and literature. 
It is difficult to define myth if we look at Bourvie's discourse. However, the eminent

scholar on myth Claude Levi-Strauss gives a very concise definition of myth. Wendy Doniger simplifies his definition in the preface of his book, Myth and Meaning (1995) aptly. According to her,

Levi-Strauss has always insisted that a myth can be translated only by another myth, never by a scientific formula (Wendy Doniger, 1995: x).

Thus in order to define myths and make sense of them we have to align a myth with another myth. Science or scientific theories cannot define myths or make sense of them.

Myths are oral narrations that have a function. Joseph Campbell describes the function of myth aptly in his work, "Four Functions of Myth" in Pathways to Bliss (Novato, CA: New World Library), pp 6-10. The four functions decribed by Campbell are,

1. ...the first function of mythology [is] to evoke in the individual a sense of grateful, affirmative awe before the monstrous mystery that is existence

2. The second function of mythology is to present an image of the cosmos, an image of the universe round about, that will maintain and elicit this experience of awe. [or] ...to present an image of the cosmos that will maintain your sense of mystical awe and explain everything that you come into contact with in the universe around you.

3. The third function of a mythological order is to validate and maintain a certain sociological system: a shared set of rights and wrongs, proprieties or improprieties, on which your particular social unit depends for its existence.

4....the fourth function of myth is psychological. That myth must carry the individual through the stages of his life, from birth through maturity through senility to death. The mythology must do so in accords with the social order of his group, the cosmos as understood by his group, and the monstrous mystery.

The four functions that have been described above will be analyzed in the texts chosen for this research.

Campbell discusses the laws of science too. Scientists work on facts and prove and the laws of science are working hypotheses. Scientist search for facts in order to make the present theory obsolete. Campbell compares scientific theory to religious tradition. According to him,

In a religious tradition, the older the doctrine, the truer it is held to be. In the scientific tradition, on the other hand, a paper written ten years ago is already out of date. There's a continuous movement onward. So there's no law, no Rock of Ages on which you can rest. There's nothing of the kind. It's fluid. And we know that rocks are fluid, too, though it takes them a long time to flow. Nothing lasts. It all changes. In the social realm, again, we don't regard our laws as being divinely ordained (pp. 6-10).

Thus, it is appropriate to use Levi-Strauss's theory that myths can only be defined by myths because myths are traditional and come under the canon of classical literature. They sometimes in some religions work hand in hand with religious dogmas, whereas science strives to delete and deconstruct older theories. It has also deconstructed religion i.e. Freud's psychological theories and the Big Bang theory which have in most part denied the existence of God.

Hussain Othman in his essay Conceptual Understanding of Myths and Legends

In Malay History (2008) describes Malay myths that are present in three Malay classical texts: Hikayat Raja Pasai, Sejarah Melayu and Hikayat Merong Mahawangsa. His study desribes the traditional Malay myths because all three texts were written before the Portuguese colonialism of Melaka by Malay castle scribes. According to him, 
Myth means a traditional story of ostensibly historical events that serves to unfold part of the world view or explain a practice, belief or natural phenomena occurred in the past. It dwelled in Malay society as it settled in other societies as well, ever since they were in animistic lives as Berg (1965: 117) explained, "A picture of the past is a complex of myths, and as such it exists everywhere and in any period of human history." The coming of Hinduism, Buddhism and Islam did not make Malays disregard their mythical and legendary stories. In contrast they were adored and believed as a real substance especially by the peasant Malays (Yusoff Iskandar 1986: 141-142).5 In the beginning, most of the historical events were transmitted orally. Through this method of transmission many of the events turned into the mythological folkloric forms and each of the verbal sources displayed its variation. According to Davies (1994: 4) "...myths exist as part of an oral tradition and often exhibit a considerable variation of content and presentation." This is due to the difficulties to retain the historical events in its pure form especially because of the lapse of time. Historical events were then transmitted from one stage to another until finally they established position in mythical forms. Myth therefore is the final stage where the historical events and stories are preserved. Eliade (1971: 43) wrote: Myth is the last not the first - stage in the development of a hero. But this only confirms the conclusion reached by many investigators (Caraman and others): the recollection of a historical event or a real personage survives in popular memory for two or three centuries at the utmost. This is because popular memory finds difficulty in retaining individual events and real figures... The historical personage is assimilated to his mythical model (hero, etc.), while the event is identified with the category of mythical actions (fight with a monster, enemy brothers, etc.) (Hussain Othman, 2008: 93-92).

Hussain Othman has used 4 scholars to define myth. The gist of Hussain's research on the definition of myth is that myth is historical which explains a natural pehenomenon or a set of believes and is part of Malay society, it began as an oral tradition. Myths in this definition involves a hero and his development and he is a mythical model that takes part in mythical action, i.e. fighting with monsters, dragons and wicked witches or wizards to save his family or a princess. Thus, it can be concluded that a myth is not unlike a fairytale or a folklore. It falls into this category and like both it is difficult to define and it is also difficult to prove its existence based on historical facts. 


\section{The Framework}

G.S. Kirk (1984) argues in his essay "On Defining Myths" about how myths should be defined. According to him most traditional definitions of myths do not do justice to the concept of myth and are based on scientific truth that cannot be used in defining myths. Kirk believes in diversity and states that "...theories of mythical expression...suggests that mental and psychic processes of myth-formation are themselves diverse" (p. 55).

Kirk states that at a general level we have to agree that myths are tales, however not all tales are a myth (p. 56). Kirk argues,

By "myths" most people mean "primitive," unsophisticated and non-literary tales, tales that are told in non-literate cultures, that are repeated and developed by anonymous storytellers rather than being invented by an individual author with pen in hand (p. 56).

Like a tale that is recognized as a "dramatic construction with a dénouement, and most myths are of that kind" (Kirk, 1984: 56).

Kirk argues that myths may take many different forms or functions. According to him,

Beyond their basic quality as traditional oral tales, therefore, myths may take on many different forms and functions - as associated with gods and rituals, as affirmations or characters of lands, titles, institutions and beliefs, as explanations at various levels and as problem-exploring and problem-palliating in various ways, and as providing different kinds of mental relief and support. No definition of myths can easily cover all these possible uses, which overlap each other but do not coincide (1984: p.58).

Kirk argues that by rejecting the traditional and universal definitions of myth he has put "one more nail in the coffin of concept that has many weaknesses" (1984: 58). Kirk looks at the concept of rationality and irrationality with regards to myths. According to him not everything that is irrational can be said to be a myth. Based on this idea we can analyze the myths of creation that will be discussed in this essay. The question that can be put forth is "How far is the myth of creation irrational?" Thus, with this question in mind we can answer many other questions related to myth and in this case the myth of creation. Myth also has a religious quality that can be traced back to pre-Aristotalean Greek (Kirk, 1984: 59). More so the myth of creation. Thus, in order to analyze the myth of creation one might also need to look at the religious discourses that discuss the concept of creation.

Kirk disagrees with Levi-Strauss's theory that all myths are connected to a social form like Brazillian myths and also the neighbouring that are connected to the social form of Indians who have preserved and developed their myths. Kirk also repudiates the theory that that the underlying structure of myths is a universal one of the human mind (84: p. 60). However, at the same time Kirk argues that in order to analyze a myth we cannot disregard traditional ideas and definitions about myths just for the sake of taking up and using new "eclectic" ideas (1984: 60). There has to be a balanced approach when analyzing myths. There should not be too much tolerance of traditional ideas, but at the same time those ideas cannot be totally rejected. Kirk further argues that myths like dreams can be interpreted in many ways. However, the theory of the universality of myth is rejected by Kirk. He takes up Devereux's view on the flexibility of analyzing myth and the listing of their probable or possible functions and qualities (Kirk 1984: p, 61). Therefore, myths cannot be analyzed using strict traditional frameworks. The analysis of myths have to be flexible and balanced without tying the theoretical framework to much older classical and traditional theories. 
Theodor H. Gaster (1984), "Myth and Story" gives us a new way of thinking about myth. According to him science becomes outdated, thus it can be interpreted that classical theories on myth have become outdated and out of fashion thus the need to come up with new readings and a new way of looking at and analyzing myths. Archeological findings have helped in authenticating older myths and classical theories as well as in producing new theories on myth. Thus, the study of myth is not archaic much less dead. Anthropology has had a similar effect on the study of myth.

Universally it is acknowledged that myths are related to rituals. Gaster gives a very precise definition to myth and ritual. According to him myth is told while ritual is a thing done. When we connect myth to ritual it can be argued that the thing told can turn into a thing done and becomes a norm in society in time when practiced or done over and over again. Thus, myth becomes ritual.

Gaster argues that myth needs to be redefined because times have changed. Myth has "acquired a new context [and] also a new dimension" (1984: 112). Thus, myth now has to be written as Myth with a capital "M" to show its importance and the seriousness of the project. Therefore, the older concept that myth is an ideal concept has to be looked into. Under this new label - Myth - Gaster reviews the concept under two aspects "temporal and immediate...eternal and transcendental" (1984:113). He explains his concept in this manner,

The present generation, for example, is but the immediate, punctual avatar of an ideal community which transcends the here and now and in which all generations are immerged, in the same way that a moment is immerged in time. All that it does and suffers is but a concentration in the actual and empirical of that which transpires simultaneously and automatically on an ideal, pre-terpunctual level" (Gaster, 1984: 113).

It can be deduced that the present generation has been made or created from the myths of the past, through time and eternity because myths have crossed the time barrier, and have remained in this modern day and have shown us their eternal quality.

Gaster then compares myth to ritual. Myth occurs according to him while ritual transpires (1984:113). Without myth a ritual cannot transpire when it is connected to myth. Ritual means that "...certain functional procedures are adopted under communal auspices and sanctions" (113). The revival of ritual adds to the existing ideal continuum and this turns myth into Myth. Gaster further argues that myth and ritual are one and the same. They are not two different entities. He states, "Myth is cosubstantial with ritual" (Gaster, 1984:114). Both are said to be a single entity that are "viewed from two different angles or through two different prisms" (Gaster, 1984:114). Myth and ritual are argued to be a single phenomenon, thus Gaster debunks and deconstructs traditional theories on myth and rituals.

How does one define myth? At its simplest and very basic a myth according to Gaster is "an intrinsic parallelism between the real and the ideal. Myth is a verbal media for the articulation of ritual (Gaster, 1984: 114). Myth defines, explains and describes the concept of God and King and how this concept is presented across the world. However in describing God a myth lacks empirical articulation and has its limitations, unlike its presentation of the King. (Gaster, 1984: pp.119-123). Thus, we cannot rely on myths alone in defining God, we have to go back to empirical religious texts like the Bible and the Al-Quran, to name two.

The authenticity or truth of Myth is normally questioned. Gaster argues that older investigators postulated that truth is opposite fiction, thus a myth becomes truth if it can be proven with historical data and veracity 1984: 132). Gaster aligns the truth of mythic ideas to metaphysics, i.e. religion (1984:133). 


\section{Analysis}

The first myth of creation from Malaysia is titled "Asal Ususl Ka'adat". There is a young man in a village in Kudat that is ugly and less able than his friends. Everyday his friends and him go into the jungle to find 'damar'. One day in the jungle Yanak, the young man meets a very beautiful and gentle woman. She tells Yanak that she has come from another world to look for a husband. In her world, her people are not as gentle as she is, and she does not fit in. Thus, she has to marry a human husband. Although Yanak is not as good looking as his friends the woman marries him.

Ka'adat is a type of bird that inhabits the Kudat jungle. "Asal Usul Ka'adat" is the myth of creation of this bird. Yanak and his wife has a son from their marriage. This boy later is turned into a Ka'adat by his mother because his father goes against his mother's wishes.

Before marriage Yanak is asked to honour a few terms. One of them is that he cannot touch needles and cotton and he cannot put up a night at his family's home. Yanak agrees to the terms, no one else can know about them. One day when Yanak goes back to meet his family, he tells his sister what those terms are. His sister puts a needle and cotton in his head gear and he touches them. Upon touching them he turns into an ugly man again.

His wife is angry that he did not honour their marriage terms. Thus she decides to part from her husband. She kills their child by throwing him onto the floor and he turns into a Ka'adat. This type of bird exists until today in Kudat. When men go out into the jungle to look for damar they can be heard making noises. Most people who look for damar will stop looking for damar, turn back and go home.

The above myth can be read using the four functions of myth introduced by Campbell. The first function that evokes awe is present since an ugly man marries a beautiful supernatural being that presents itself to the man in the form of a woman. The second function that myth presents mythical awe of the cosmos is present. The woman is mythic and the mythical awe is that after the marriage the man becomes good looking and rich. The third function that is to maintain a certain sociological system is also present. Society exists on law and truthfulness. The man made a promise to the woman to abide by certain rules while married to her. Once he breaks the promise the marriage ceases to exist and the child borne together dies at the hands of the mother. The fourth function, the psychological function is also present even if not in its entirety. The myth carries the man through a few stages in life marriage, fatherhood and later the collapse of his marriage and the death of his child. It ends in tragedy as does life since it is the universal trait of life that every living being except God will die.

The second myth of creation from Malaysia is titled "Asal Usul Padi". It is a myth about how the paddy plant came into being. The story is about a husband and wife who are farmers and their seven children. The farmer dreams and in his dream an old man tells him to kill all his children one by one on a land in the jungle. He says that if Pak Ali, the farmer, does not sacrifice his children he will not have any children to continue his lineage. Without consulting his wife Pak Ali follows the orders of the man in his dreams whom he suspects is satan (239-248).

Later, he moves to the land with his wife. On the land where he has killed all his children grows the paddy plant. Pak Ali and his wife, have another seven children who all behave and look like their late seven children. Pak Ali becomes a rich man and as the children grow up he always advices them to respect rice because it has been created from human lives. He says that it has a soul too and when it is not respected it cries, talks and much 
more. The only difference is that humans cannot see and listen to all that because most human do not have the sixth sense. That is why until now when humans cannot finish the rice that they eat they are advice to feed it to animals. It is not advisable to throw it away or waste it so that the rice does not cry (248).

This myth cannot be analysed using the four functions of myth, because this story diverts from Hussain Othman's definition of the myth. Othman argues that a myth involves a hero who fights supernatural beings in order to save his family from harm. However, in the above myth Pak Ali follows the orders of Satan and kills all his children, so that his lineage will not become extinct. In the place where he commits this crime sprouts the paddy plant which is the staple food of the Malays. Thus, a father is shown as heartless and he feeds his seven new children from the plants that have grown at the site of the children that he murdered. This myth of creation shows that man is willing to kill and destroy his own children in order to live since he views procreation as a very easy step. The story shows that in the end Pak Ali lives happily with his seven new children, but the ghost of what he did haunts him. This is due to the fact that he reminds his children to treat rice with dignity because it has a soul, the soul that was created from the death of his seven previous children.

The first Australian myth of creation that will be analyzed in this essay is titled "The First Men and Women", discusses the inter-relationship between animals and man. It is also about the inter-changeability of animal life forms.

This myth portrays two myths of creation, first the myth of the creation of a crow and second the myth of the creation of men. It is said that the first man and woman lived amicably together without procreating. One day the woman wanted a child. So the man created a baby from clay and put it in the woman's body. When it was old enough the woman gave birth to it. Thus, this is the way that this first man and woman procreated and filled this world with babies.

This same story carries the story of metamorphoses. It states,

One of the most astounding series of metamorphoses began with a mosquito. Instead of completing its life cycle in the usual manner, it increased in size and shape and turned into a blowfly. Sometime after assuming this form it swelled up again and became a moth. The most startling transition when the moth changed into a small bird, the process ending when the small bird in turn became a crow (p. 86).

The text also states,

In time they settled down to a working partnership, each with his or her own duties. Two children were born, each to a different totem. For protection against danger, the mother kept them hidden in a tree, but one day, when both parents were away from the encampment, the children scrambled down from their perch. Once they reached the ground they took on human form and became the earliest Aboriginals from whom all others are ascended. The Kurnai tribe, which lives in the eastern coastal districts of Victoria, substitutes the Pelican for the Crow, and identifies his woman as Tuk, the Musk-duck.

The above myth has all four functions that Campbell describes. The monstrous mystery of existence in the two myths above is the creation of humans. The first myth states that humans are created from clay and put in a woman so that she can give birth, while the second story is about the metamorphoses of an insect that later becomes a crow and marries a human wife which later gives birth to human children. The second function that a myth present an image of the cosmos and awe is the birth of the human and the awe at how the first humans are created. The sociological system has to maintained according to the third function Thus in this story a man 
and a woman has to get married and procreate. The psychological function is that a marriage entails humans to give birth. There is death present in the second story, that is how the Crow gets to marry the dead man's wife.

The second myth is "The Discovery of Fire". According to the text,

Every tribe had its own version of the origin of fire. The versions have a certain uniformity. An animal of some species gains possession of the fire and refuse to part with it. After various skirmishes it is taken from its guardian, by guile or by force, and distributed to those who have need of it. The first example comes from Victoria, the second from the Northern Territory (p. 136-137).

The text also states,

The women belonging to a tribe that lived near the present city of Melbourne were endeavouring to extract honey from an ants' nest when they were attacked by a swarm of snakes. They fought desperately, striking at them with their fighting sticks. One of them missed the snake at which it was aimed and struck a boulder, breaking in two. A sheet of flame flew out of one of the broken ends. A Crow that was perched on an overhanging branch was fascinated by the unusual sight. It swooped down, snatched the broken piece up in its beak, and sped away. While the women were still trying to kill the snakes, two men happened to see the trail of smoke left by the Crow as it flew overhead. They ran after it as fast as they could, shouting and throwing stones at it. The startled Crow dropped the stick, which fell into the long grass and started a conflagration...The Great Father, Punjel, took the men to his home in the sky and told them that the gift of fire must never be allowed to go out. He showed them how to use it to cook food and warm themselves on cold nights, warning them that it must never be allowed to break lose again. They paid heed to his words, but after a while grew careless and allowed their campfire to die. Soon the world was as fireless as before the fire came from the woman's fighting stick. (137).

The ending of the text is an advice to mankind,

'Punjel warns you that this is the last chance that you will have to preserve fire,' they told the men who had gathered on the mountain top. 'But because he wishes you well, we will teach you how to make fire by rubbing two sticks together in a special way' (138).

The above myth "The Discovery of Fire" can be read by Theodor H. Gaster (1984), "Myth and Story". This myth has to be written with a capital $\mathrm{M}$ as Myth because it involves the theory of creation as well as ritual. Fire in many civilizations is connected to religious rituals. In Hinduism it is said that the first speck of fire was brought down from heaven thus named as "Agni Shastri" which means the Sacred Fire (Alamgir Hashmi, 2000). In Islam it is said that fire was brought into this world from hell, and from a speck it has become what it is today.

The above story relates that fire has to be kindled and taken care of since it is part of our lives and it is a very important part. Without it man would cease to exist because in certain societies where there is winter it warms the body and around the world it is used to cook. This gives us a new way of thinking about myth. Thus the Myth of fire is important because in certain religions such as Hinduism many rights cannot be performed without fire. One of them is the right of marriage. A bride and a groom has to walk around a kindled holy fire seven times before their marriage is acknowledged as legal and lawful. Therefore the Myth of fire, using Gaster's view, becomes immediate and eternal. Immediate because it is a very important substance in our daily lives, and eternal because fire has to and will exist until the end of time since man cannot live without it. 


\section{CONCLUSION}

Myths are indeed sacred narratives. The above myths show the theory of creation working. The theory of creation is sacred. It can be found in many religious texts, like the Al Quran, the Bible and the Mahabharata to name a few. Myths maybe said to be unreliable narratives, however sacred myths like the myths of creation are important. Via the myths mankind tries to search for the truth and most of the time they stumble upon religion because the story of creation exists in religious texts too. This research has been and inter-disciplinary study of myths of creations from two countries, Malaysia and Australia. The myths are aboriginal myths of creation and they hold to a similar theme that the myth of creation is actually sacred.

\section{REFERENCES}

Abdul Halim Bandan. 2006. Cerita Tradisi Sabah Pelbagai Kaum. Kuala Lumpur: Dewan Bahasa dan Pustaka.

Bouverie, Synoǿve des. 2002. The definition of myth. Symbolical phenomena in ancient culture. pp.11-69 online httpsdigitalt.uib. nobitstreamhandle1956.22960The\%20Definition\%20of\%20Myth_\%20des\%20Bouvrie. pdfsequence $=1$ retrieved 27/07/2016

Campbell, Joseph. "Four Functions of Myth" . From Pathways to Bliss (Novato, CA: New World Library), pp 6-10.

Dundes, Alan. 1984. Sacred Narrarive: Readings in the Theory of Myth. Berkely: University of California Press.

Hussain Othman. 2008. Conceptual Understanding of Myths and Legends in Malay History. Sari (2008) 91-110.

Levi-Strauss, Claude. 1995. Myth and Meaning. New York: Shocken Books.

Reed, A.W. 1978. Aboriginal Myths: Tales of the Dreamtime. Sydney: Reed New Holland.

Citation: Halimah Mohamed Ali, "The Myth of Creation From Malaysia and Australia: A Comparative Study". American Research Journal of Humanities and Social Sciences, Volume 3, 2017; pp:1-10

Copyright (C) 2017 Halimah Mohamed Ali, This is an open access article distributed under the Creative Commons Attribution License, which permits unrestricted use, distribution, and reproduction in any medium, provided the original work is properly cited. 